\title{
Water Use Efficiency of Soybean under Different Tillage and Irrigation Methods
}

\author{
Manal A. El-Nady ${ }^{*}$ and Wafa M. Hadad** \\ *Soil Science Department, Faculty of Agriculture, Cairo \\ University, Giza and ${ }^{* *}$ Ministry of Water Resources and \\ Irrigation, Irrigation Development Sector, Cairo, Egypt.
}

\begin{abstract}
A FIELD study was carried out during two growing seasons of 2012/2013 and 2013/2014 at the Water Requirements Research Station, Water Management Research Institute, Kafer El-Sheikh Governorate to compare two irrigation methods, surge (SI) and alternate $(\mathrm{AI})$ with traditional furrow irrigation method (FI) in relation to two tillage systems, conventional (CT) and no-tillage (NT) on water use efficiency and crop yield production of soybean. In both seasons, the lowest amount of irrigation water was applied with AI treatments, whereas, the highest amount of irrigation water was applied with FI treatments. The irrigation water amounts were saved by using AI and SI methods. The AI and SI saved about $29.0 \%$ and $15.0 \%$ of water applied in comparison with FI under CT and NT systems. Irrigation water productivity (IWP) and crop water use efficiency (CWUE) were higher when applying AI compared to SI and FI under both tillage systems. Surge irrigation had the potential to improve irrigation application efficiency (AE) followed by AI compared to FI. The highest seed yield and yield attributes were obtained with FI followed by SI and AI in both seasons, respectively. Significant differences in seed yield, yield attributes and plant growth characteristics were found only between FI and AI under CT and NT. The SI surpasses the AI in obtaining higher seed yield, yield attributes without any significant reduction of soybean yield. These results suggesting that an extra irrigation water amount may be saved without any significant loss in yield of soybean when applying SI method under both tillage systems. The results also showed the effect of CT on reducing applied water and increasing irrigation water productivity and crop water consumptive use compared to NT. However, no significant difference between the two tillage systems in yield and yield attributes was found. Values of ETc should be adjusted according to the used irrigation and tillage methods. The crop water stress index (CWSI) has proven to be a good indicator for monitoring and quantifying water stress of soybean with different irrigation methods and tillage systems.
\end{abstract}

Keywords: Surge irrigation, Alternative irrigation, Furrow irrigation, Conventional tillage, No- tillage, Water productivity, Crop water use efficiency, Yield, Yield attribut ETc, Soybean.

Irrigation and seedbed preparation are major factors in crop production. Any chosen irrigation and tillage methods should aims at maximizing crop yield. 
Therefore, improving irrigation water productivity in agriculture sector, as the main water user, is the key factor in resolving water shortage problems. A great effort has been made on saving water in agriculture, especially in optimizing irrigation methods. Surface irrigation according to the FAO (2012), is the oldest and most widely used method for irrigating agricultural lands across the world and the water use efficiencies of surface irrigation methods are significantly low in case of improper or insufficient field preparations. Pereira et al. (2002) and Norwood \& Dumler (2002) reported that identifying proper measures and practices, including irrigation water saving practices is required for the water scarcity regimes to increase water productivity and reduce costs. Several effective irrigation management patterns were achieved such as, limited irrigation and surge flow irrigation (Horst et al., 2007). Surge and alternative irrigation methods are used to reduce the negative impacts of over irrigation due to surface irrigation, (Xiao et al., 2004). When comparing surge irrigation and conventional furrow irrigation, the surge irrigation flow with variable time cycles increased the application efficiency and reduced water volume by more than $80 \%$ compared to continuous irrigation (Rodriguez et al., 2004). Mostafazadeh - Fard et al. (2006) indicated that water advance along the furrows was faster for surge flow as compared to the continuous flow. Ali and Talukder (2008) also indicated that using surge irrigation increased water productivity in crop production. Therefore, Jensen and Shock (2001) and Sial et al. (2006), considered surge irrigation as a strategy for furrow irrigation. In respect to alternate irrigation method, Tang et al. (2005) and Du et al. (2006) found that alternate irrigation may maintain a reasonable crop yield and save irrigation water; it has been proved to be an effective irrigation way for many crops in many areas. Agele et al. (2002) pointed that the relationship between soil and water requirements of crops is basic to understand adaptation and yield stability. Benjamin et al. (1997) found that the placement of irrigation water either in every furrow or only in alternate-furrow had no effect on corn plant development, growth or grain yield. However, Li et al. (2007) found that alternative irrigation decreased total dry mass of sweet maize by $6.7 \%$ and increased water use efficiency by $24.3 \%$ compared to conventional irrigation under the fertilization and well-watered condition. Kang and Zhang (2004) reported that advanced irrigation methods that increase irrigation water efficiency and provide a balance between the crop water requirements and available water of the soil should be applied through soil tillage practices to maximize their benefits on soil productivity. Tillage methods affect the sustainable use of soil resources through its influence on soil properties, proper tillage can improve soil related constraints, while improper tillage may cause a range of undesirable processes such as destruction of soil structure, depletion of organic matter content and fertility (Rashidi et al., 2010). The no-till (NT) and the conventional tillage (CT) systems have been found to have large influence on soil moisture and crop yields (Agriculture and Rural Development, 2004). The effect of tillage methods on yield of soybean is inconsistent, it has been reported to be variable among years (Norwood, 1999 and Singer et al., 2008) or higher with NT, (Temperly and Borges, 2006) or higher with CT, (Fecak et al., 2010 and Lasisi \& Aluko, 2009). Therefore, Jabro et al. (2009) indicated that it is essential to select a tillage practice that sustains the soil physical

Egypt. J. Soil Sci. 56, No. 2 (2016) 
properties required for successful growth of agricultural crops. In recent years, soybean production has gained importance and it is produced in largest amounts in the world, it is an annual legume that is primarily produced to be used as food or as a source of edible oil for human consumption (Liener, 1994 and Balat \& Balat, 2010). The integration of appropriate tillage and irrigation systems is a challenge in order to maximize their benefits on soil productivity. The objectives of this study were to compare the effect of three irrigation methods in relation to two tillage systems on water productivity, crop water use efficiency, yield and yield attributes of soybean crop.

\section{Material and Methods}

\section{Description of the study area}

A field experiment was carried out at El-Karada ,Water Requirements Research Station, Water Management Research Institute, Kafer El-Sheikh Governorate during the two successive summer seasons of 2012/2013 and $2013 / 2014$. The station is located at $31^{\circ} 07^{\circ} \mathrm{N}$ to $30^{\circ} 52^{\wedge} \mathrm{E}$ and at an altitude of $6.0 \mathrm{~m}$ above sea level. The soil at the experimental site is predominantly clay.

\section{Experimental design and general preparations}

The experimental area was $600 \mathrm{~m}^{2}$ designed as randomized complete block design with three replications. The area of study was divided into two blocks each of the blocks was further divided into three subplots of $20 \mathrm{~m}$ long and $5 \mathrm{~m}$ wide. A buffer of $1.5 \mathrm{~m}$ in width was between plots.

\section{Soil sampling}

The soil physical and chemical properties were measured at the initiation of the experiment. Soil samples were taken randomly from depths of 0-20, 20-40 and 40-60 cm, respectively. The physical properties: bulk density, field capacity and wilting point (Table 1) were determined according to Klute (1986). The chemical properties: $\mathrm{pH}$, electrical conductivity and organic matter content (Table 2) were determined according to page et al. (1982).

\section{Irrigation and tillage treatments}

The adopted treatments were as follows:

1-Main- plot (tillage systems)

I- Conventional tillage (CT).

II- No-tillage (NT).

\section{2- Sub-plot (irrigation methods)}

I- Traditional furrow irrigation (FI), in which every furrow is irrigated.

II- Surge-furrow irrigation (SI), in which the water is cycled on and off (15 minon -times and $10 \mathrm{~min}$ - off - times) during each irrigation.

III- Alternate- furrow irrigation (AI), in which irrigated furrow in irrigation event will be un-irrigated in the next irrigation events and vice versa for the following irrigation. 
TABLE 1. Particle size distribution, bulk density (Bd), field capacity (F.C) and wilting point (W.P) of the experimental soil (average of the two seasons)

\begin{tabular}{|l|c|c|c|}
\hline \multirow{2}{*}{$\begin{array}{c}\text { Soil } \\
\text { characteristics }\end{array}$} & \multicolumn{3}{|c|}{ Soil depth $(\mathrm{cm})$} \\
\cline { 2 - 4 } & $\mathbf{0 - 2 0}$ & $\mathbf{2 0 - 4 0}$ & $\mathbf{4 0 - 6 0}$ \\
\hline Sand \% & 20.6 & 18.9 & 20.8 \\
\hline Silt \% & 28.1 & 25.3 & 30.2 \\
\hline Clay \% & 51.3 & 55.8 & 49.0 \\
\hline Texture class & Clay & Clay & Clay \\
\hline Bd $\left(\right.$ Kg. ${ }^{-3}$ ) & 1.12 & 1.21 & 1.30 \\
\hline F.C (vol.\%) & 45.2 & 42.3 & 39.2 \\
\hline W.P (vol.\%) & 24.2 & 23.8 & 21.5 \\
\hline
\end{tabular}

TABLE 2. Chemical properties of the experimental soils (average of the two seasons)

\begin{tabular}{|c|c|c|c|c|c|c|c|c|c|c|}
\hline \multirow{3}{*}{$\begin{array}{c}\text { Soil } \\
\text { depth } \\
\text { (cm) }\end{array}$} & \multicolumn{2}{|c|}{ pH 1:2.5 } & \multirow{3}{*}{$\begin{array}{c}\text { EC } \\
\text { dS.m }{ }^{-1}\end{array}$} & \multirow{2}{*}{\multicolumn{4}{|c|}{ Cation (meq. $\left.\mathrm{L}^{-1}\right)$}} & \multicolumn{3}{|c|}{$\operatorname{Anion}\left(\right.$ meq..$\left.^{-1}\right)$} \\
\hline & \multicolumn{2}{|c|}{ Growth Season } & & & & & & & & \\
\hline & $2012 / 2013$ & 2013/2014 & & $\mathrm{Ca}^{++}$ & $\mathbf{M g}^{++}$ & $\mathrm{Na}^{+}$ & $\mathbf{K}^{+}$ & $\mathrm{HCO}_{3}^{--}$ & $\mathrm{Cl}^{-}$ & $\mathrm{So}_{4}^{--}$ \\
\hline $0-20$ & 7.89 & 18.3 & 1.98 & 1.45 & 3.15 & 3.80 & 0.15 & 2.35 & 2.70 & 3.50 \\
\hline $20-40$ & 7.49 & 7.52 & 1.91 & 2.00 & 1.60 & 6.50 & 0.16 & 3.75 & 2.90 & 3.61 \\
\hline $40-60$ & 7.23 & 7.21 & 0.88 & 1.90 & 2.20 & 7.40 & 0.16 & 2.25 & 3.00 & 6.41 \\
\hline
\end{tabular}

Irrigation water applied (IWa)

Irrigation water applied (IWa) was controlled through measurements of the soil moisture content in the subsequent soil depths [0-20, 20-40 and 40-60 $\mathrm{cm}$ ] by using the gravimetric method. All the plots were irrigated when the soil available moisture content in the soil profiles was depleted to $50 \%$. The irrigation water amounts were measured using a rectangular shape crested weir. The discharge of irrigation water was calculated using the following formula according to Massoud (1967).

$\mathrm{Q}=\mathrm{CL} \mathrm{H} \mathrm{H}^{3 / 2}$

where,

$\mathrm{Q}$ : The discharge $\left(\mathrm{m}^{3} \cdot \mathrm{S}^{-1}\right)$

$\mathrm{L}:$ The length of the crest $(\mathrm{m})$

$\mathrm{H}$ : The measured head above the crest (m)

$\mathrm{C}$ : Discharge coefficient, 0.6 , empirically obtained.

Irrigation water productivity (IWP)

Irrigation water productivity (IWP) was calculated according to Jensen (1983), as follows:

IWP $=\frac{Y}{I W a} \quad$ where,

$\mathrm{Y} \quad=$ Total seed yield $(\mathrm{kg} / \mathrm{fed}$.

IWa $=$ Total applied water $\left(\mathrm{m}^{3} /\right.$ fed. $)$

Egypt. J. Soil Sci. 56, No. 2 (2016) 
Water consumptive use (WCU)

Water consumptive use (WCU) was calculated using the following equation according to Hansen et al. (1979).

$\mathrm{WCU}=\sum_{i=1}^{1=3} \mathrm{D}_{1} \times \mathrm{D}_{\text {bi }} \times \frac{\theta_{2}-\theta_{1}}{100} \quad$ where,

$\mathrm{WCU}=$ Water consumptive use in the effective root zone $(0.60 \mathrm{~m})$.

$\mathrm{D}_{\mathrm{i}} \quad=$ Soil layer depth $(0.20 \mathrm{~m})$.

$\mathrm{D}_{\mathrm{bi}}=$ Soil bulk density, $\left(\mathrm{Kg} . \mathrm{m}^{-3}\right)$ for the $0.60 \mathrm{~m}$ soil depth.

$\theta_{1}=$ Soil moisture $\%$ before irrigation.

$\theta_{2}=$ Soil moisture \% 48 hours after irrigation.

I $\quad$ Number of soil layers.

Crop water use efficiency (CWUE)

Crop water use efficiency (CWUE) was calculated according to Jensen (1983), as follows:

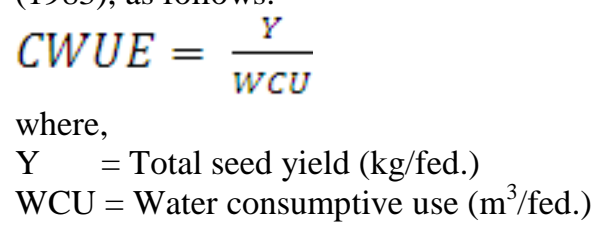

Water stored at the root zone (Ws)

Water stored at the root zone (Ws) was determined by taking soil sample two weeks after tillage application and at 10 days intervals until harvest. Samples were taken by auger from each layer then the volumetric water content was multiplied by the thicknesses of the respective soil layers.

Irrigation application efficiency $(A E)$

Irrigation application efficiency (AE) was calculated according to James (1988), as follows:

$A E=\frac{W_{S}}{I W a} \quad$ where,

Ws = Amount of water stored in the root zone, $\mathrm{m}^{3}$

IWa = Irrigation water applied, $\mathrm{m}^{3}$

Reference evapotranspiration (ETo)

The climatic data collected from the meteorological station close to the experimental crop field. The reference evapotranspiration (ETo) calculated using The FAO Penman-Monteith equation (Table 3) according to Allen et al. (1998).

Crop water requirements (ETc)

Crop water requirements (ETc) were estimated according to Allen et al. (1998) using the following equation:

$\mathrm{ETc}=\mathrm{ETo} \times \mathrm{Kc}$

where,

ETc $=$ Crop water requirements, $\mathrm{mm}$. 
Kc $=$ Crop coefficient.

ETo $=$ Reference evapotranspiration, $\mathrm{mm}$

TABLE 3.The meteorological data and average ETo (mm/day) of 2012/2013 and 2013/2014 seasons.

\begin{tabular}{|c|c|c|c|c|c|c|c|c|c|c|}
\hline Month & \multicolumn{5}{|c|}{$\mathbf{2 0 1 2 / 2 0 1 3}$} & \multicolumn{5}{|c|}{$\mathbf{2 0 1 3 / 2 0 1 4}$} \\
\cline { 2 - 11 } & $\begin{array}{c}\mathbf{T}_{\max } \\
\mathbf{C}^{\circ}\end{array}$ & $\begin{array}{c}\mathbf{T}_{\min } \\
\mathbf{C}^{\circ}\end{array}$ & $\begin{array}{c}\text { Wind-sp } \\
\mathbf{K m} / \mathbf{h}\end{array}$ & $\begin{array}{c}\mathbf{R H} \\
\mathbf{\%}\end{array}$ & $\begin{array}{c}\mathbf{E T}_{\mathbf{0}} \\
\mathbf{m m}\end{array}$ & $\begin{array}{c}\mathbf{T}_{\max } \\
\mathbf{C}^{\circ}\end{array}$ & $\begin{array}{c}\mathbf{T}_{\text {min }} \\
\mathbf{C}^{\circ}\end{array}$ & $\begin{array}{c}\text { Wind-sp } \\
\mathbf{K m} / \mathbf{h}\end{array}$ & $\begin{array}{c}\mathbf{R H} \\
\mathbf{\%}\end{array}$ & $\begin{array}{c}\mathbf{E T}_{\mathbf{0}} \\
\mathbf{m m}\end{array}$ \\
\hline May & 31.3 & 19.7 & 4.2 & 50.9 & 5.55 & 29.6 & 19.6 & 4.6 & 52.5 & 5.46 \\
\hline June & 33.6 & 22.7 & 4.2 & 55.5 & 6.21 & 30.8 & 21.5 & 5.1 & 56.5 & 6.05 \\
\hline July & 35.6 & 25.1 & 4.4 & 57.6 & 6.51 & 31.1 & 22.8 & 5.3 & 59.6 & 6.10 \\
\hline Aug. & 35.9 & 26.0 & 4.0 & 56.1 & 6.33 & 32.7 & 24.1 & 4.5 & 59.5 & 6.01 \\
\hline Sep. & 32.8 & 25.0 & 4.1 & 57.2 & 5.01 & 31.1 & 24.6 & 6.8 & 60.6 & 5.30 \\
\hline
\end{tabular}

Crop coefficient $(\mathrm{Kc})$

Crop coefficient $(\mathrm{Kc})$ was calculated using the following equation according to Allen et al. (1998):

$\mathrm{Kc}=\mathrm{ETa} / \mathrm{ETo}$

where,

$\mathrm{ETa}=$ actual evapotranspiration.

Crop water stress index (CWSI)

Crop water stress index (CWSI) expressed in terms of evapotranspiration based on Jackson et al. (1981).

CWSI $=1-$ ETc/ ETo where,

$\mathrm{ETc}=$ The actual crop evapotranspiration.

ETo $=$ The reference evapotranspiration.

In theory, CWSI progress from zero for non-stressed plants to 1 for severely stressed plants.

\section{Planting}

Soybean (Glycine max L.) seeds variety of (Giza 111) were sown on 3 and 10 May of the first and second seasons, respectively, and harvested on September 1 and 5 of the first and second seasons, respectively. The seeds were sown at a row spacing of $20 \mathrm{~cm}$. All recommended agricultural practices and fertilization regime for soybean production were done according to the recommendation of the Ministry of Agriculture.

At harvest, ten individual plants were chosen at random from each plot for measurement of number of pods/ plant, 100-seed weight (gm), plant height

Egypt. J. Soil Sci. 56, No. 2 (2016) 
$(\mathrm{cm})$ and shoot weight $(\mathrm{gm})$. The seed yield $(\mathrm{kg} / \mathrm{fed}$.) was estimated from an area of $\left(1 \mathrm{~m}^{2}\right)$.

\section{Statistical analysis}

Data of the different treatments was subjected to analysis of variance (ANOVA) and the treatments means were compared using the LSD at 0.05 level according to Gomez and Gomez (1984). The t- test was also used to establish the significant difference of Kc, ETc and CWSI for the different treatments. CROPWAT for Windows Version 8.0 was used to estimates ETo from the weather station data.

\section{Results and Discussions}

Irrigation water applied (IWa) and water consumptive use (WCU)

Data of the amounts of irrigation water applied (IWa) and measured seasonal water consumptive use (WCU) for all irrigation methods and tillage treatments during the two growing seasons were presented in Table 4 . The data showed the significant effect of irrigation methods on the irrigation water applied. The highest amount of irrigation water was recorded with FI treatments; while the lowest ones were recorded with AI treatments during the two successive seasons. The SI treatments received lower amount of irrigation water than FI. Irrigation water applied with SI was lower by about $15.0 \%$ compared to FI. On the other hand, the AI reduced applied irrigation water by $29.0 \%$ compared to FI. These results are in agreement with Li et al. (2007), Abdel-Maksoud et al. (2002) and El-Sherbeny et al. (1997). The results revealed that it is possible to limit the amount of applied irrigation water, when there is a water shortage, by using alternative irrigation method. The data also showed that irrigation water applied under NT was higher than CT. Ghazanfar et al. (2010) explained that the significant increase in applied water under NT may be due to the higher evaporation during the growing period. The highest water applied was accompanied with the highest consumptive use obtained with FI treatments, which consumed more water than SI and AI treatments. The increase in WCU was due to the higher water application with FI which provides chance for more consumption of water that ultimately resulted in increasing WCU. Seasonal WCU were ranged between $2265-1661 \mathrm{~m}^{3}$ and between $2280-1679 \mathrm{~m}^{3}$ under CT in the first and second seasons, respectively. Whereas, under NT ranged from 2360 $1702 \mathrm{~m}^{3}$ and from $2380-1723 \mathrm{~m}^{3}$ in the first and second seasons, respectively. Khan et al. (2003) and Öz, (2008) reported that water consumption of soybean was between $1890-2940 \mathrm{~m}^{3}$ based on water stress levels. In this concept, the AI treatments reduced WCU by $26.7 \%$ and $27.9 \%$, whereas, SI treatments reduced WCU by $10.82 \%$ and $12.29 \%$ under CT and NT, respectively in comparison to FI. The WCU under CT was lower than WCU under NT. Tillage affects water consumption by changing soil permeability, evaporation water consumption of plants. The total applied irrigation water and the water consumptive use values of all treatments were close in both seasons, that of the second year being slightly higher. This may be attributed to differences in climatic conditions and planting date. A strong linear relationship between WCU and applied irrigation amount 
( $\mathrm{R} 2=0.98)$ was found. The regression equation was as follows: $\mathrm{WCU}=$ 179.10+0.72 IWa .

TABLE 4. Irrigation water applied (IWa) and water consumptive use (WCU) as affected by different irrigation methods and tillage systems of 2012/2013 and 2013/2014 seasons.

\begin{tabular}{|c|c|c|c|c|c|}
\hline \multirow{2}{*}{$\begin{array}{c}\text { Tillage } \\
\text { systems }\end{array}$} & \multirow{2}{*}{$\begin{array}{c}\text { Irrigation } \\
\text { methods }\end{array}$} & \multicolumn{2}{|c|}{$\mathbf{2 0 1 2 / 2 0 1 3}$} & \multicolumn{2}{c|}{$\mathbf{2 0 1 3 / 2 0 1 4}$} \\
\cline { 3 - 6 } & & $\begin{array}{c}\text { IWa } \\
\left(\mathbf{~ m}^{\mathbf{3}} / \mathbf{f e d} .\right)\end{array}$ & $\begin{array}{c}\text { WCU } \\
\left(\mathbf{m}^{\mathbf{3}} / \mathbf{f e d} .\right)\end{array}$ & $\begin{array}{c}\text { IWa } \\
\left(\mathbf{~ m}^{\mathbf{3}} / \mathbf{f e d} .\right)\end{array}$ & $\begin{array}{c}\text { WCU } \\
\left(\mathbf{m}^{\mathbf{3}} \text { /fed. }\right)\end{array}$ \\
\hline \multirow{3}{*}{ CT } & FI & 2930 & 2265 & 3000 & 2280 \\
\cline { 2 - 6 } & SI & 2530 & 2020 & 2595 & 2040 \\
\cline { 2 - 6 } & AI & 2083 & 1661 & 2106 & 1679 \\
\hline \multirow{2}{*}{ Mean } & & $\mathbf{2 5 1 4}$ & $\mathbf{1 9 8 2}$ & $\mathbf{2 5 6 7}$ & $\mathbf{1 9 9 9}$ \\
\hline \multirow{2}{*}{ NT } & FI & 3005 & 2360 & 3060 & 2380 \\
\cline { 2 - 6 } & SI & 2550 & 2070 & 2600 & 2091 \\
\cline { 2 - 6 } & AI & 2130 & 1702 & 2170 & 1723 \\
\hline Mean & & $\mathbf{2 5 6 1}$ & $\mathbf{2 0 4 4}$ & $\mathbf{2 6 1 0}$ & $\mathbf{2 0 6 4}$ \\
\hline LSD 5\% & & 64.69 & 101.87 & 81.51 & 123.15 \\
\hline
\end{tabular}

Irrigation water productivity (IWP)

Effect of irrigation methods and tillage systems on IWP is shown in Table 5. The IWP evaluates the efficiency of water utilization by the crop, depending upon the total water applied and seed yield obtained. The highest IWP (0.62 and 0.59 in the first season and 0.58 and 0.55 in second ones under CT and NT, respectively) was obtained with $\mathrm{AI}$ in comparison to FI and SI. The AI increased IWP by about $26.0 \%$ and $12.0 \%$ compared to FI and SI, respectively under both tillage systems. The AI yielded higher IWP values since AI consumed less water than FI and SI methods. These results concluded that the effect of AI on increasing IWP was more than the effect of SI. Significant differences among irrigation methods on IWP under both tillage systems were found. Arora et al. (2011) indicated that the IWP of soybean was affected by irrigation and tillage methods. On the other hand, IWP under CT was higher than under NT; the increase in IWP was about $7.8 \%$ and $8.2 \%$ compared to NT in the first and second seasons, respectively. However, no significant difference in IWP was found between the two tillage systems. Howell (2001) indicated that depletion of water resources has led to improvements in water productivity through enhanced management practices and irrigation. The regression equation for the relationship between IWP and irrigation water applied (IWa) was obtained as follows:

IWP $=0.878-0.00014$ IWa. A highly significant inverse relationship between them was obtained $\left(\mathrm{R}^{2}=0.92\right)$.

Crop water use efficiency (CWUE)

Data presented in Table 5 show the crop water use efficiency (CWUE) under different irrigation methods and tillage systems. The highest CWUE in both seasons was obtained with alternative furrow irrigation followed by surge irrigation compared to continuous furrow irrigation at the two seasons. These

Egypt. J. Soil Sci. 56, No. 2 (2016) 
results demonstrated that the crop water use efficiency increased with the decrease of water applied and the increase of water consumption. Therefore, applying AI method could enhance CWUE followed by SI method for soybean crop. This was in agreement with Okasha et al. (2013). The increase in CWUE with AI and SI may be due to reducing transpiration water loss of soybean plants and soil water consumption compared to FI. The CWUE was affected by the tillage methods; CWUE was higher with CT treatments than NT. Statistically, a significant difference was found in CWUE between the two tillage systems. The results indicated that AI and SI optimizing crop water use efficiency under both tillage systems compared to FI method. This result agreed with Rosegrant et al. (2002).

TABLE 5. Irrigation water productivity (IWP) and crop water use efficiency (CWUE) as affected by different irrigation methods and tillage systems in 2012/2013 and 2013/2014 seasons.

\begin{tabular}{|c|c|c|c|c|c|}
\hline \multirow{2}{*}{$\begin{array}{c}\text { Tillage } \\
\text { systems }\end{array}$} & \multirow{2}{*}{$\begin{array}{c}\text { Irrigation } \\
\text { methods }\end{array}$} & \multicolumn{2}{|c|}{$\mathbf{2 0 1 2 / 2 0 1 3}$} & \multicolumn{2}{|c|}{$\mathbf{2 0 1 3 / 2 0 1 4}$} \\
\cline { 3 - 6 } & & $\begin{array}{c}\text { IWP } \\
\left(\mathbf{k g . m}^{-3}\right)\end{array}$ & $\begin{array}{c}\mathbf{C W U E} \\
\left(\mathbf{k g . ~}^{-3}\right)\end{array}$ & $\begin{array}{c}\text { IWP } \\
\left(\mathbf{k g . m}^{-3}\right)\end{array}$ & $\begin{array}{c}\text { CWUE } \\
\left(\mathbf{k g . ~}^{-3}\right)\end{array}$ \\
\hline \multirow{2}{*}{ CT } & FI & 0.49 & 0.63 & 0.47 & 0.62 \\
\cline { 2 - 6 } & SI & 0.55 & 0.69 & 0.53 & 0.68 \\
\cline { 2 - 6 } Mean & AI & 0.62 & 0.78 & 0.59 & 0.75 \\
\hline \multirow{2}{*}{ NT } & FI & 0.55 & $\mathbf{0 . 7 0}$ & $\mathbf{0 . 5 3}$ & $\mathbf{0 . 6 8}$ \\
\cline { 2 - 6 } & SI & 0.52 & 0.58 & 0.45 & 0.57 \\
\cline { 2 - 6 } & AI & 0.58 & 0.72 & 0.51 & 0.63 \\
\hline Mean & & $\mathbf{0 . 5 2}$ & $\mathbf{0 . 6 5}$ & $\mathbf{0 . 5 0}$ & $\mathbf{0 . 6 3}$ \\
\hline \multirow{2}{*}{ LSD } & & 0.043 & 0.043 & 0.039 & 0.047 \\
$5 \%$ & & & & & \\
\hline
\end{tabular}

Water stored in the root zone (WS)

Data of soil water stored (WS) in the upper $60 \mathrm{~cm}$ of soil depth, is presented in Fig. 1. The WS in the root zone increased as the irrigation amounts increased. Water stored in the root zone followed the order of $\mathrm{FI}>\mathrm{SI}>\mathrm{AI}$ under both tillage systems in both seasons. Stored water under FI was higher by $11.5 \%$ and $39.2 \%$ under CT and by $14.7 \%$ and $41.9 \%$ under NT as compared to SI and AI, respectively. The WS under NT treatments was higher than WS under CT treatments. The increase in water stored under NT treatments was due to the effect of NT on retaining more water in the root zone of the soil. Hatfield et al. (2001) explained that in no-tillage system, WS in the soil profile is generally more as compared to CT, due to reduced soil evaporation, increased infiltration, reduced deep percolation and due also to the increase in soil organic matter. Statistically, significant differences between FI and each of SI and AI and also between SI and AI were obtained, (LSD 5\% 90.58). Moreover, the WS of the first season was lower than those of the second

one. This may be due to the difference in the amounts of irrigation water applied and environmental conditions. 


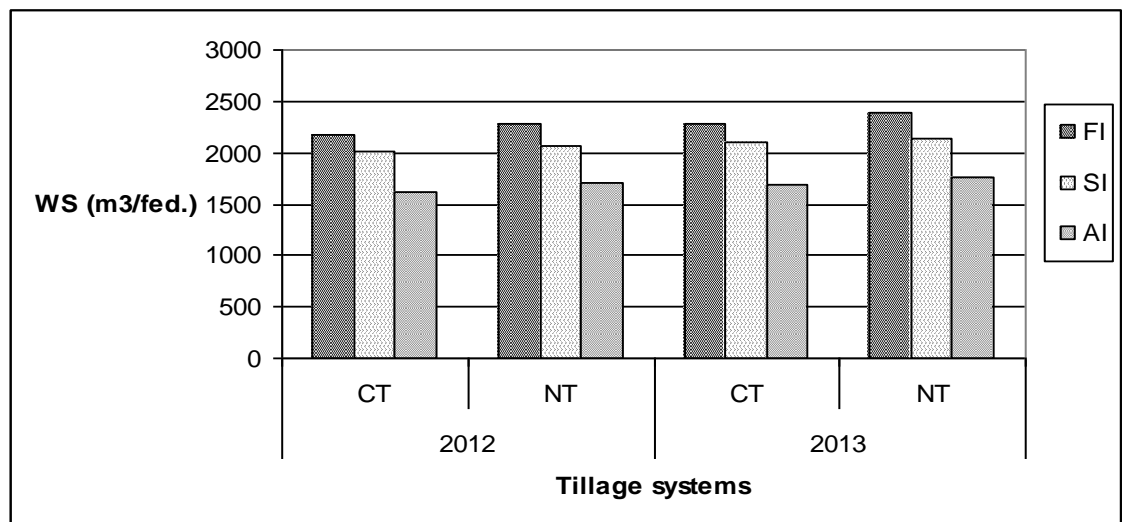

Fig. 1. Water stored (WS) in the root zone under different irrigation methods and tillage treatments of $2012 / 2013$ and $2013 / 2014$ seasons.

Irrigation application efficiency $(A E)$

Table 6 illustrates irrigation application efficiency (AE) for irrigation methods under tillage and no-tillage systems. The highest $\mathrm{AE} \mathrm{(} 80$ and 81 in the first season and 81 and 82 in the second one) was recorded with SI, whereas the lowest AE was recorded with FI (74 and 76 in the first season and 76 and 78 in the second one). These results are in agreement with Mohmed et al. (2014) and Horst et al. (2007). The highest AE obtained with SI revealed that lower amount of applied water was wasted or was not available for the crop as compared to FI. This result may be attributed by the fact that surge technique offered greater opportunity time for water to infiltrate in the soil. In contrast, the lowest $\mathrm{AE}$ of FI resulted from the non uniform distribution and excessive waste of water. The increase in $\mathrm{AE}$ was also obtained with AI as compared to FI. A significant difference between FI and AI was found under both tillage systems in both seasons. In respect to tillage systems, AE increased with NT treatments as compared with CT treatments. However, no significant difference in AE between CT and NT treatments was found. These results indicated that surge irrigation proved to be more effective to improve water irrigation efficiency for soybean crop.

TABLE 6. Irrigation application efficiency $\%$ as affected by different irrigation methods and tillage systems in 2012/2013 and 2013/2014 seasons

\begin{tabular}{|c|c|c|c|c|c|c|}
\hline \multirow[b]{2}{*}{ Season } & \multirow{2}{*}{$\begin{array}{c}\text { Tillage } \\
\text { systems }\end{array}$} & \multicolumn{5}{|c|}{ Irrigation methods } \\
\hline & & FI & SI & AI & Mean & $\begin{array}{c}\text { LSD } \\
\mathbf{5 \%}\end{array}$ \\
\hline \multirow[t]{2}{*}{$2012 / 2013$} & CT & 74 & 80 & 78 & 77 & \multirow[t]{2}{*}{2.96} \\
\hline & NT & 76 & 81 & 80 & 79 & \\
\hline \multirow[t]{2}{*}{$2013 / 2014$} & CT & $\overline{76}$ & 81 & $\overline{79}$ & $\overline{78}$ & \multirow[t]{2}{*}{2.52} \\
\hline & NT & 78 & 82 & 81 & 80 & \\
\hline
\end{tabular}

Egypt. J. Soil Sci. 56, No. 2 (2016) 


\section{Yield of soybean}

Figure 2 shows the effect of different irrigation and tillage methods on yields of soybean during the two studied seasons. The seed yield ranged from 1421 to 1235 $\mathrm{Kg} / \mathrm{fed}$. in the first season and from 1410 to $1206 \mathrm{Kg} / \mathrm{fed}$. in the second one for the different irrigation and tillage methods. Data illustrated that seed yield was higher when applied irrigation water increased. The increase in seed yield followed the order of FI > SI > AI under both tillage systems in both seasons. As for the effect of SI, the seed yield was insignificantly reduced in comparison to FI. On the other hand, seed yield with SI was higher than the seed yield obtained with AI. The increase in seed yield with SI was $8.12 \%$ and $7.37 \%$ in the first season and $10.10 \%$ and $9.20 \%$ in the second one under CT and NT, respectively in comparison to AI. Dealing with the effect of AI on seed yield, under CT, AI reduced seed yields by $9.4 \%$ and $7.5 \%$ in the first season and by $11.2 \%$ and $9.1 \%$ in the second ones as compared to FI and SI, respectively. The same results were obtained with the second season. A significant difference between FI and AI was found whereas, no significant difference was found between FI and SI or between SI and AI in both seasons. These results revealed that soybean crop will suffer yield loss when applying alternative method due to water deficit compared to FI and SI. The SI maintained a reasonable crop yield as compared with AI therefore; surge irrigation method is beneficial for saving water without significant yield loss. The increase in seed yield under FI is mainly due to enough existence soil moisture in the root zone, whereas, the reduction of soybean yield with SI and AI could be attributed to soil water shortage with these methods. The yield of soybean responded positively $(\mathrm{R} 2=0.69)$ to irrigation water applied (IWa) as follows: Yield $=918.40+0.16$ IWa. A positive linear relationship $\left(R^{2}=0.68\right)$ was also obtained between the water consumptive use (WCU) and yield of soybean for the two seasons as follows: Yield $=886.40+220.2 \mathrm{WCU}$. Dealing with the effect of tillage systems, the seed yield under CT, increased by $6.2 \%$ and $5.4 \%$ over NT in the first and second seasons, respectively. This may be explained that tillage improves soil conditions by altering soil structure, moisture holding capacity, mechanical impedance to root penetration, aggregate size distribution and hydraulic conductivity which in turn, affects plant growth. The combination between FI and CT recorded the highest seed yield in both seasons. Whereas, the combination between AI and NT recorded the lowest seed yield.

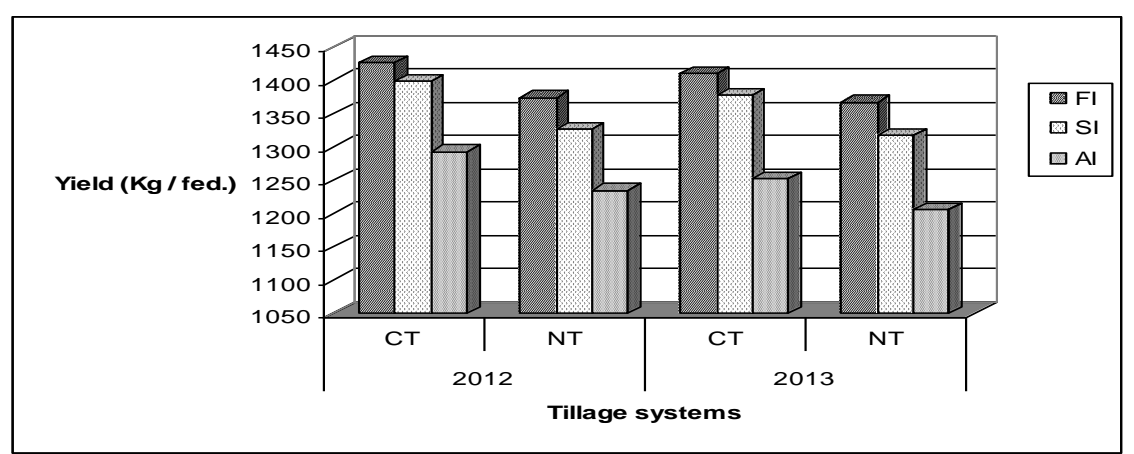

Fig. 2. Yield of soybean as affected by irrigation methods and tillage systems in 2012/2013 and 2013/2014 seasons (LSD 5\%= 127.61).

Egypt. J. Soil Sci. 56, No. 2 (2016) 


\section{Yield attributes}

The effect of irrigation methods and tillage systems on some plant growth characteristics (plant height and shoot weight) and yield attributes (number of pods/plant and 100 seed weight) of soybean during the two growing seasons are shown in Table 7 . The changes in yield attributes with irrigation methods were due to the changes in irrigation method performance. The FI might have favored the progressive growth of plant as better soil moisture was maintained and significantly increased the studied components of soybean as compared to SI and AI. Applying AI method enlarged the reduction percentage at all studied plant characteristics and yield attributes of soybean with respect to FI and SI methods. A significant difference between FI and AI was found in plant height and shoot weight, no of pods and 100- seed weight in both seasons while, the difference between SI and AI was not significant under both tillage systems in both seasons.

TABLE 7. Some plant growth characteristics and yield attributes of soybean affected by irrigation methods and tillage systems in 2012/2013 and 2013/2014 seasons

\begin{tabular}{|c|c|c|c|c|c|c|c|c|c|}
\hline $\begin{array}{c}\text { Tillage } \\
\text { systems }\end{array}$ & $\begin{array}{c}\text { Irrigation } \\
\text { methods }\end{array}$ & \multicolumn{4}{|c|}{$\mathbf{2 0 1 3 / 2 0 1 2}$} & \multicolumn{4}{|c|}{$\mathbf{2 0 1 3 / 2 0 1 4}$} \\
\cline { 3 - 10 } & & $\begin{array}{c}\text { Plant } \\
\text { height } \\
\text { (cm) }\end{array}$ & $\begin{array}{c}\text { Shoot } \\
\text { weight } \\
\text { (gm) }\end{array}$ & $\begin{array}{c}\text { No.of } \\
\text { pods/ } \\
\text { plant }\end{array}$ & $\begin{array}{c}\mathbf{1 0 0 -} \\
\text { seed } \\
\text { weight } \\
\text { (gm) }\end{array}$ & $\begin{array}{c}\text { Plant } \\
\text { height } \\
\text { (cm) }\end{array}$ & $\begin{array}{c}\text { Shoot } \\
\text { weight } \\
\text { (gm) }\end{array}$ & $\begin{array}{c}\text { No.of } \\
\text { pods/ } \\
\text { plant }\end{array}$ & $\begin{array}{c}\mathbf{1 0 0} \\
\text { seed } \\
\text { weight } \\
\text { (gm) }\end{array}$ \\
\hline \multirow{2}{*}{ CT } & FI & 127 & 152.54 & 128.00 & 23.74 & 124 & 155.23 & 124 & 23.48 \\
\cline { 2 - 10 } & SI & 122 & 140.00 & 95.67 & 20.73 & 120 & 145.75 & 97 & 21.74 \\
\cline { 2 - 10 } & AI & 117 & 127.30 & 86.00 & 19.16 & 114 & 124.45 & 83 & 19.30 \\
\hline Mean & & $\mathbf{1 2 2}$ & $\mathbf{1 3 9 . 9 5}$ & $\mathbf{1 0 3 . 2 2}$ & $\mathbf{2 1 . 2 1}$ & $\mathbf{1 1 9 . 3}$ & $\mathbf{1 4 1 . 8 1}$ & $\mathbf{1 0 1 . 3 3}$ & $\mathbf{2 1 . 5 1}$ \\
\hline \multirow{2}{*}{ NT } & FI & 108 & 123.15 & 112.67 & 22.51 & 107 & 119.70 & 102 & 21.40 \\
\cline { 2 - 10 } & SI & 103 & 117.32 & 84.70 & 18.85 & 101 & 115.00 & 82 & 19.60 \\
\cline { 2 - 10 } & AI & 99 & 101.65 & 79.00 & 17.26 & 97 & 103.15 & 75 & 17.92 \\
\hline Mean & & $\mathbf{1 0 3}$ & $\mathbf{1 1 4 . 0 4}$ & $\mathbf{9 2 . 1 2}$ & $\mathbf{1 9 . 5 4}$ & $\mathbf{1 0 1 . 7}$ & $\mathbf{1 1 2 . 6 2}$ & $\mathbf{8 6 . 3 3}$ & $\mathbf{1 9 . 6 4}$ \\
\hline \multirow{2}{*}{$\begin{array}{c}\text { LSD } \\
5 \%\end{array}$} & & 8.86 & 23.12 & 17.32 & 4.17 & 7.69 & 14.68 & 15.04 & 3.32 \\
\hline
\end{tabular}

However, a consistent trend for higher no.of pods and 100-seed weight obtained with CT compared to NT, no significant difference between the two tillage systems was found. The effect of CT on yield attributes may be due to the good seed bed providing for cultivated plant under CT (Latifi et al., 2009).

Crop coefficients (Kc) and crop water requirement (ETc)

Data in Table 8 shows the values of the crop coefficient $(\mathrm{Kc})$ and crop water requirement $(\mathrm{ETc})$ for each irrigation method under tillage systems during the two successive growing seasons. Maximum Kc value was recorded with FI followed by SI and AI, respectively. Also, the Kc values were higher with NT compared to CT in both seasons however, no significant difference was found in $\mathrm{Kc}$ between the two tillage systems. The ETc values were changed with the irrigation methods. Data of ETc showed a range of 567.9-399.2 mm over the two tillage systems and the two seasons. The highest ETc values recorded for FI and

Egypt. J. Soil Sci. 56, No. 2 (2016) 
the lowest ETc value was recorded with AI. The reduction in crop water requirement with $\mathrm{AI}$ is a way of saving amount of applied water. The data also showed that the ETc values is modified by the tillage system, the ETc under NT were higher than CT. Also the estimated ETc for the second season was higher than the first one. This is mainly attributed to the lower values of ETo in the second season compared to the first one. A significant difference in ETc values among irrigation methods was obtained as shown in Table 9.

\section{Crop water stress index (CWSI)}

Table 8 shows the crop water stress index (CWSI) for the different irrigation and tillage treatments. The CWSI is an index detecting crop water stress and it quantifies the combined effects of soil water, atmospheric and crop conditions on crop water status. The CWSI should progress from zero for non-stressed plants, to 1 for severely stressed plants. The obtained CWSI values ranged from 0.24 to 0.46 for the first season and 0.18 to 0.42 for the second one with different irrigation methods under the two tillage systems. The obtained CWSI values indicated that plants of soybean were subjected to appropriate irrigation conditions. However, AI treatments had the highest CWSI values. The lowest CWSI values were recorded with FI and SI treatments, respectively under both tillage systems in the first and second seasons.

TABLE 8. Crop coefficient (Kc), crop water requirement (ETc) and crop water stress index (CWSI) under different irrigation and tillage methods for 2012/2013 and 2013/2014 seasons

\begin{tabular}{|c|c|c|c|c|c|c|c|}
\hline \multirow{2}{*}{$\begin{array}{c}\text { Tillage } \\
\text { systems }\end{array}$} & \multirow{2}{*}{$\begin{array}{c}\text { Irrigation } \\
\text { methods }\end{array}$} & \multicolumn{3}{|c|}{$\mathbf{2 0 1 2 / 2 0 1 3}$} & \multicolumn{3}{|c|}{$\mathbf{2 0 1 3 / 2 0 1 4}$} \\
\cline { 2 - 8 } & Kc & ETc & CWSI & Kc & ETc & CWSI \\
\hline \multirow{2}{*}{ CT } & FI & 0.73 & 539.62 & 0.27 & 0.78 & 540.24 & 0.22 \\
\cline { 2 - 8 } & SI & 0.65 & 480.48 & 0.35 & 0.70 & 484.83 & 0.29 \\
\cline { 2 - 8 } & AI & 0.54 & 399.17 & 0.46 & 0.58 & 401.71 & 0.42 \\
\hline \multirow{3}{*}{ NT } & Mean & $\mathbf{0 . 6 4}$ & $\mathbf{4 7 3 . 0 9}$ & $\mathbf{0 . 3 6}$ & $\mathbf{0 . 6 9}$ & $\mathbf{4 7 5 . 5 9}$ & $\mathbf{0 . 3 1}$ \\
& FI & 0.76 & 561.79 & 0.24 & 0.82 & 567.94 & 0.18 \\
\cline { 2 - 8 } & SI & 0.67 & 495.26 & 0.33 & 0.72 & 498.68 & 0.28 \\
\cline { 2 - 8 } & AI & 0.55 & 406.56 & 0.45 & 0.59 & 408.64 & 0.41 \\
\hline & Mean & $\mathbf{0 . 6 6}$ & $\mathbf{4 8 7 . 8 7}$ & $\mathbf{0 . 3 4}$ & $\mathbf{0 . 7 1}$ & $\mathbf{4 9 1 . 7 5}$ & $\mathbf{0 . 2 9}$ \\
\hline
\end{tabular}

The highest CWSI values indicated that plants of soybean were subjected to conditions of water stress. A significant difference in CWSI between the FI and AI was found whereas, no significant difference between FI and SI was found (Table 9). 
TABLE 9. T-test values (over the two seasons) for the difference between irrigation methods on (Kc, ETc and CWSI) under the two tillage systems

\begin{tabular}{|c|c|c|c|c|c|c|c|}
\hline & & \multicolumn{6}{|c|}{ T-value } \\
\hline \multirow{3}{*}{$\begin{array}{c}\text { Tillage } \\
\text { systems }\end{array}$} & \multirow{2}{*}{$\begin{array}{c}\text { Irrigation } \\
\text { methods }\end{array}$} & \multicolumn{6}{|c|}{ Irrigation methods } \\
\hline & & \multicolumn{3}{|c|}{ SI } & \multicolumn{3}{|c|}{ AI } \\
\hline & & $\mathrm{Kc}$ & ETc & CWSI & $\mathrm{Kc}$ & ETc & CWSI \\
\hline \multirow[t]{2}{*}{ CT } & FI & $2.26^{*}$ & 26.07 & $1.92 *$ & 6.09 & 106.70 & 6.09 \\
\hline & SI & - & - & - & 3.59 & 32.64 & 3.32 \\
\hline \multirow[t]{2}{*}{ NT } & FI & $2.43 *$ & 19.29 & $2.43 *$ & 6.10 & 48.45 & 6.10 \\
\hline & SI & - & - & - & 3.90 & 44.65 & 3.90 \\
\hline
\end{tabular}

*Not significant

\section{Conclusion}

The results concluded that soybean yield depends on the total water applied during the growing season. The FI had higher yields than SI and AI due to sufficient supplied water in FI. Surge and alternative irrigation prove to be a water saving methods. The two methods increased irrigation water productivity, crop water use efficiency and irrigation application efficiency in comparison to continuous irrigation. However, AI increased IWP and CWUE, it may not be a beneficial practice in increasing soybean yield significantly in comparison with FI method whereas, surge flow irrigation method maintained yield comparable with continuous flow irrigation method. The results also showed that no-tillage system can be applied as it reduces production costs relative to conventional tillage (CT).

\section{References}

Abdel-Maksoud, H.H., Othman, Sanaa, A., and El-Tawil, A.Y. (2002) Improving water and $\mathrm{N}$-use utilization for field crops via alternate furrow irrigation technique 1-Maize crop. J. Agric. Sci., Mansoura Univ., 27(12), 8761-8769.

Agele, S.O., Olufayo, A., Iremiren, G.O. (2002) Effects of season of sowing on water use and yield of tomato in the humid south of Nigeria. African Crop Sci. J. 10, 231-237.

Agriculture and Rural Development (2004) Tillage effects on soil moisture. Available at: http://www1.agric.gov.ab.ca/\$department/ deptdocs.nsf/all/ eng8174/\$file// Tillage_ Effects_on_Soil_Moisture.pdf ?OpenElement. [Accessed June 14, 2006].

Ali, M. H. and Talukder, M. S. U. (2008) Review increasing water productivity in crop production-A synthesis. Agric. Water Manage. 95, 1201-12013. DOI: 10.1016/j.agwat 2008.06.008.

Allen, R.G., Pereira, L.S., Raes, D. and Smith, M. (1998) Crop evapotranspiration Guidelines for computing crop water requirements. FAO Irrigation and Drainage Paper, No. 56, FAO, Rome. 
Arora, V. K., Singh, C. B., Sidhu, A. S. and Thind, S. S. (2011) Irrigation, tillage and mulching effects on soybean yield and water productivity in relation to soil texture. Agric. Water Manage. 98, 563-568.

Balat, M. and Balat, H. (2010) Progress in biodiesel processing. Applied Energy, 87(6), pp 18151835.

Benjamine, J.G., Porter, L.K., Duke, H.R. and Ahuja, L.R. (1997) Corn growth and nitrogen uptake with furrow irrigation and fertilizer bands. Agron. J. 89, 609 - 612.

Du, T. S., Kang, S. Z., Zhang, J. H. and Li, F. S. (2006) Yield and physiological responses of cotton to partial root-zone irrigation in the oasis field of northwest China. Agric. Water Manage. 84, 41-52.

El-Sherbeny, A. M., Ward, M.I.H. and El-Behery, A. A. (1997) Evaluation of alternate irrigation technique under furrow irrigation system. Proc. 5th Conf.of Misr Soc.of Agric. Eng. Towards a National Strategy for Agr. Eng. In Egypt for the Next Decade. 161-172.

FAO (2012) Guidelines for designing and evaluating surface irrigation systems. FAO Corporate Document Repository, Available: http:// www.fao.org

Fecak, O., Sarikova, D. and Cerny, I. (2010) Influence of tillage system and starting N fertilization on seed yield and quality of soybean Glycine max (L.) Merrill. Plant, Soil and Environ. 56, 105-110.

Ghazanfar, M., Asoodar, M. A. and Alami Saeed, K. H. (2010) The effect of conservation tillage, planting and irrigation methods on water use efficiency and wheat grain yield in north of Ahwaz. Journal of Engineering and Appl. Sci. 5(2), 101-105.

Gomez, K. A. and Gomez, A. A. (1984) Statistical Procedures for Agriculture Research. A Wiley-Inter Science Publication, john Wiley \&Sons, Inc. New York, USA.

Hansen, V. W., Israelsen, D. W. and Stringharm, Q. E. (1979) Irrigation Principle and Practices, $4^{\text {th }}$ ed. John Wiley \& Sons., New York.

Hatfield, J. L., Sauer, T. J. and Prueger, J. H. (2001) Managing soils to archive greater water use efficiency: A review. Agron. J. 93, 271-280.

Horst, M. G., Shamutalov, Sh. S., Goncalves, J. M. and Pereira, L. S. (2007) Assessing impacts of surge-flow irrigation on water saving and productivity of cotton. Agric. Water Manage. 87, 115-127.

Howell, T. A. (2001) Enhancing water use efficiency in irrigated agriculture. Agron. J. 93, 281-289.

Jabro, J.D., Stevens, W.B., Evans, R.G. and Invrsen, W.M. (2009) Tillage effects on Physical properties in two soils of the Northern Great Plains. Appl. Eng. Agric. 25 (3), 377-382.

Jackson, D., Idso, B., Reginato, J. and Pinter, J. (1981) Canopy temperature as a crop water stress indicator. Water Resources Res. 17, 1133-1138, ISSN 1133-1138. 
James, L.G. (1988) Principles of Farm Irrigation System Design. Jone Willey \& Sons, PP. 543. New York, USA.

Jensen, L. and Shock, C. C. (2001) Strategies for reducing irrigation water use, Oregon state University, EM 8783, www. extension.oregonstate.edu/catalog/pdf/em/em 8783. Pdf.

Jensen, M. E. (1983) Design and operations of farm irrigation systems. The Amer. Soci. of Agric. Engin. An ASAE monogram No 3.

Kang, S. Z. and Zhang, J. H. (2004) Controlled alternate partial root zone irrigation: its physiological consequences and impact on water use efficiency. J. Exp. Bot. 55 (407), 2437-2446.

Khan, A. Z, Shah, P., Khalil, S. K. and Taj, F. H. (2003) Influence of planting date and plant density on morphological traits of determinate and indeterminate soybean cultivars under temperate environment. J. Agron. 2,146-152

Klute, A. (1986) Methods of Soil Analysis. Part 1. $2^{\text {nd }}$ ed. ASA and SSSA. Madison, Wisconsin, USA.

Lasisi, D. and Aluko, O. B. (2009) Effects of tillage methods on soybean growth and yield in a tropical sandy loam soil. Inter. Agroph., 23, 147-153.

Latifi, N., Siyahmarguei, A., Akram-Ghaderi, F. and Yones-Abadi, M. ( 2009) Effect of tillage methods on weed population dynamics in the cotton fields (Gossypium hirsutum L) Planted after canola.(Brassica napus) J. Agric. Res. 7 (1), 195-203.

Li, F., Liang, J., Kang, S. and Zhang, J. (2007) Benefits of alternate partial root-zone irrigation on growth, water and nitrogen use efficiencies modified by fertilization and soil water status in maize. Plant Soil, 295, 279-291.

Liener, I.E. (1994) Implications of antinutritional components in soybean foods. Critical Reviews in Food Science and Nutrition, 34(1), pp 3167.

Massoud, F. 1. (1967) Water Soil and Plant Relationship. New Publication-House, Alexandria.

Mohmed, A. E. E., Abd -Elmonem, E. M. and Salah, A. S. (2014) Effect of some techniques on long furrow irrigation efficiency. International Conference on Biological, Civil and Environmental Engineering (BCEE-2014) March 17-18, Dubai (UAE)

Mostafazadeh - Fard, B., Osroosh, Y. and Eslamion, S. (2006) Development and Evaluation of an Automatic Surge Flow Irrigation System. J. Agric. and Social Sci. 2 (3), 129-132.

Norwood, C.A. (1999) Water use and yield of dry land row crops as affected by tillage. Agron. J. 91, 108-115.

Norwood, C. A. and Dumler, T. J. (2002) Transition to dry land agriculture: Limited irrigation vs. dry land corn. Agron. J. 94, 310-320.

Egypt. J. Soil Sci. 56, No. 2 (2016) 
Okasha , E. M., Abdelraouf , R. E. and Abdou, M. A. A. (2013) Effect of Land Leveling and Water Applied Methods on Yield and Irrigation Water Use efficiency of Maize (Zea mays L.) Grown under Clay Soil Conditions. World Appl. Sci. J. 27 (2), 183-190. ISSN 1818-4952. () IDOSI Publications, 2013. DOI: 10.5829/idosi.wasj. 2013. 27.02.13614.

Öz, M. (2008) Nitrogen rate and plant population effects on yield and yield components in soybean. African J. of Biotec. 7 (24), 4464-4470.

Page, A. L., Miller, R. H. and Keeney, D. R. (1982) Methods of Soil Analysis Part 2: Chemical and Microbiological Properties, $2^{\text {nd }}$ ed., Amer. Soc. of Agron., Madison, Wisconsin, USA.

Pereira, L.S., Oweis, T. and Zairi, A. (2002) Irrigation management under water scarcity.Agric. Water Manag. 57, 175-206.

Rashidi, M., Keshavarzpour, F. and Gholami, M. (2010) Effect of different tillage methods on yield and yield components of tomato (Lycoperiscon esculentum). J. of Agric. and Bio. Sci. 5(2), 26 - 30.

Rodríguez, J. A., Díaz, A., Reyes, J. A. and Pujols, R. (2004) Comparison between surge irrigation and conventional furrow irrigation for covered black tobacco cultivation in Ferralsol soil. Spanish J. Agric. Res. 2(3), 445-458.

Rosegrant, M. W., Cai, X. and Cline, S. A. (2002) Global Water Outlook to 2025 , Averting an impending Crisis, Food Policy Report, A 2020 Vision for Food, Agriculture, and the Environment Initiative. International Food Policy Research Institute (IFPRI) and International Water Management Institute (IWMI). Colombo, Srilanka.

Sial, J. K., Khan, M. A. and Ahmd, N. (2006) Performance of surge irrigation under Borders. Pak. J. Agri. Sci. 43 (3-4), 186-192.

Singer, J.W., Logsdon, S. D. and Meek, D.W. (2008) Soybean growth and seed yield response to tillage and compost. Agron. J.100, 1039-1046.

Temperly, R. J. and Borges, R. (2006) Tillage and crop rotation impact on soybean grain yield and composition. Agron. J. 98, 999-1004.

Tang, L. S., Li, Y. and Zhang, J. H. (2005) Physiological and yield responses of cotton under partial root-zone irrigation. Field Crops Res. 94, 214-223.

Xiao, J., Lei, T.W., Jiang, P. F. and Yu, Y. D. (2004) Effects of water quality in furrow irrigation on corn yield and soil salinity. An ASAE/CSAE Meeting presentation Paper No. 042037, 1-4 August Ottawa, Ontario, Canada.

(Received 17/5/2015;

accepted 30/10/2015) 


\section{كفاءة إستخدام المياه لفول الصويا تحت طرق خدمة ورى مختلفة}

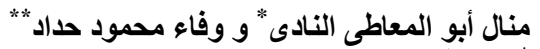

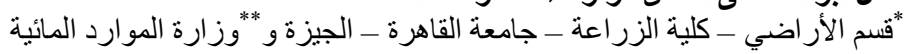

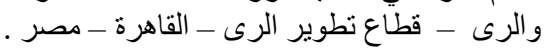

أجريت التجربة الحقلية خلال موسمى الصيف لعامى 2013/2012

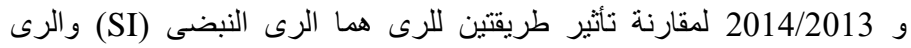

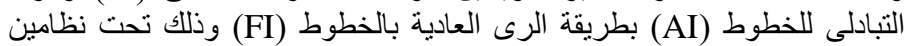

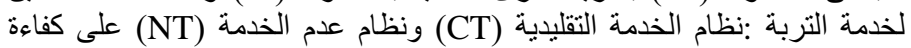

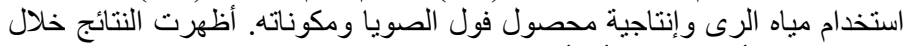

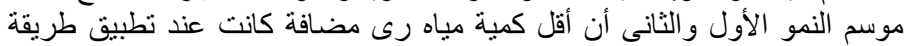

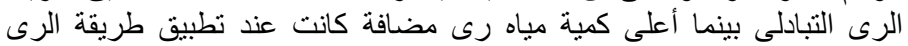

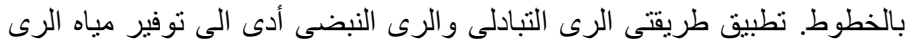

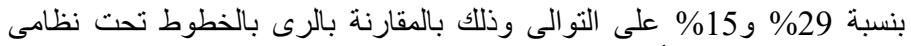

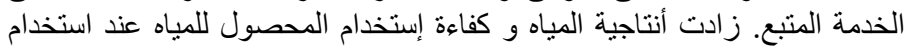

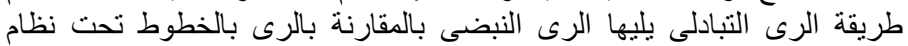

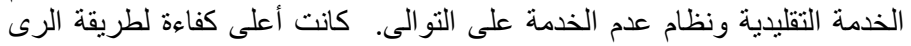

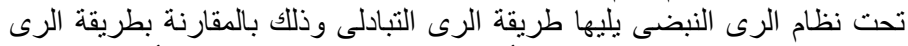

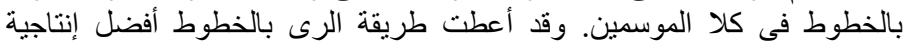

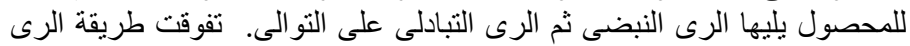

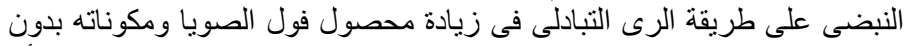

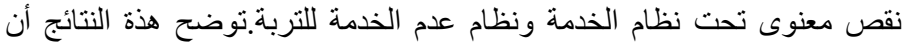

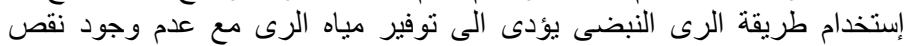

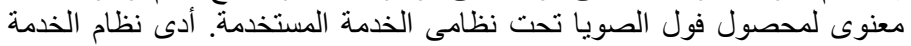

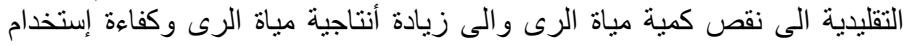

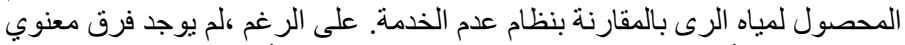

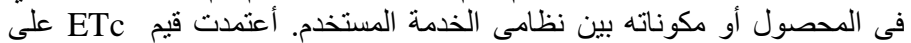

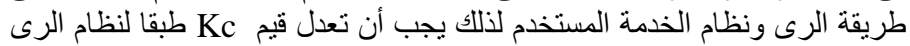

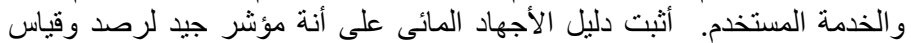
الأجهاد المائي للمحصول مع طرق الرئ دلئ الرى وخدمة التربة المختلفة. 
